\title{
Discussion
}

\section{Is Forgiveness the Deliberate Refusal to Punish?}

\author{
Brandon Warmke \\ Department of Philosophy, University of Arizona \\ Tucson, AZ 85721, USA \\ bwarmke@email.arizona.edu
}

\begin{abstract}
In his paper, "The Paradox of Forgiveness" (this Journal 6 (2009), p. 365-393), Leo Zaibert defends the novel and interesting claim that to forgive is deliberately to refuse to punish. I argue that this is mistaken.
\end{abstract}

\section{Keywords}

forgiveness, intention, overt blame, private blame, punishment

In his paper, "The Paradox of Forgiveness," Leo Zaibert defends the novel and interesting claim that to forgive is deliberately to refuse to punish. ${ }^{1} \mathrm{I}$ argue that this is mistaken.

\section{Zaibert on Forgiveness}

Sometimes we forgive others for their actions (or omissions, or consequences of their actions or omissions). ${ }^{2}$ The most commonly held account of forgiveness claims that, roughly, to forgive someone for her past wrongful harm against you is to overcome the resentment you experience towards her because

1 Leo Zaibert, 'The Paradox of Forgiveness,' Journal of Moral Philosophy 6 (2009), pp. 365-393.

2 For ease of expression, I'll suppress these latter two disjuncts and speak about forgiveness for actions. 
of what she did. ${ }^{3}$ Call this the Resentment View. There have been many different incarnations of this view throughout the literature, but we need not rehearse the details. ${ }^{4}$ Other accounts of forgiveness have been offered, but none has gained as much attention as the Resentment View. ${ }^{5}$ Standard accounts of forgiveness therefore see forgiveness primarily as involving the forswearing or overcoming of resentment, and this is why Zaibert's account is novel, for he argues that forgiveness involves the forswearing of punishment.

Zaibert's account of forgiveness is highly nuanced so we shall need to do some background work first. We can begin with Zaibert's account of blame. He writes:

A blames B for Xing, when:

(1) A believes that $X$ is wrong,

(2) A believes that $\mathrm{X}$ is an action of $\mathrm{B}$,

(3) A believes that B is a moral agent,

(4) A believes that there are no excuses, justifications or other circumstances which would preclude blame,

(5) A believes that the world would have been a better place had B not done X.

(6) A believes that the world would be a better place if something would happen to B, something which would somehow offset B's Xing.

(7) B's having Xed tends to make A feel something negative, i.e., a reactive emotion, like outrage, indignation or resentment. ${ }^{6}$

3 It is a testament to this view's popularity among philosophers that John Kekes ('Blame versus Forgiveness,' The Monist 92 (2009), p. 490) and Leo Zaibert ('The Paradox of Forgiveness', p. 388) both have recently labeled it the "standard view." Defenders of the view are legion and include Jeffrie Murphy, Getting Even: Forgiveness and Its Limits (Oxford: Oxford University Press, 2003), Charles Griswold, Forgiveness: A Philosophical Exploration (Cambridge: Cambridge University Press, 2007), and Stephen Darwall, The Second Person Standpoint: Morality, Respect, and Accountability (Cambridge, MA: Harvard University Press, 2006).

${ }^{4}$ For example, there is disagreement about what resentment is. Some think of it as a "hostile feeling" which aims at inflicting harm on the offender (e.g. Eve Garrard and David McNaughton, 'In Defence of Unconditional Forgiveness,' Proceedings of the Aristotelian Society 103 (20022003), pp. 39-60), while others think of it as a feeling of "moral protest" (e.g. Pamela Hieronymi, 'Articulating an Uncompromising Forgiveness,' Philosophical and Phenomenological Research LXII (2001), pp. 529-555), while some others think of resentment as a kind of "moral anger" (e.g. Paul Hughes, 'What is Involved in Forgiving?' Philosophia 25 (1997), pp. 33-49). Some have understood the view to mean that resentment must be permanently eliminated (e.g. Joram Haber, Forgiveness: A Study (Totowa: Rowman and Littlefield, 1991), p. 7), while others argue that resentment must only be moderated (e.g. Margaret Holmgren, 'Forgiveness and the Intrinsic Value of Persons', American Philosophical Quarterly 30 (1994), pp. 341-2).

5 For example, on Richard Swinburne's "Moral Debt View" of forgiveness, to forgive is to cancel the "moral debt" that one has against an offender because of what she did. See his Responsibility and Atonement (Oxford: Oxford University Press, 1989). On Joram Haber's "Linguistic View," forgiveness is paradigmatically a performative utterance. See his Forgiveness: A Study, 1991.

${ }^{6}$ Zaibert, 'The Paradox of Forgiveness', p. 387. 
Blame, in all of its incarnations, is therefore a private affair, for it consists solely in a syndrome of beliefs, as well as a disposition to experience certain emotions (even if the disposition is not made manifest). ${ }^{7}$ Furthermore, to act on one's blame of a wrongdoer is to punish her. One punishes, according to Zaibert, when one meets conditions (1-7), in addition to:

(8') A does something to B which A believes it is painful for B to endure, as a response to B's having Xed. ${ }^{8}$

Punishment is, as it were, blame carried out or acted upon. "To punish," he says, "is to do something about what we find blameworthy." In other words, the pain caused by punishing must be done on the basis that it would somehow offset the original wrongdoing, per condition (6). One punishes with the goal of making the world a better place by causing pain to the wrongdoer. The pain accrued to the wrongdoer "offsets" the pain caused by the original wrongdoing. To summarize: blame is private, and punishment is blame's overt manifestation.

Punishment is one way for blame to "extend" into other moral phenomena. But another way blame can be extended is by way of forgiveness, of which Zaibert distinguishes two kinds or senses. According to the first sense of forgiveness (what Zaibert calls "pure forgiveness"), A forgives B in the sense of being a "pure mental phenomenon" 10 when A blames B (i.e. conditions (1-7) hold) and:

(8) A believes that the world would in fact be a worse place if she [i.e. A] did something to $\mathrm{B}$ in response to her wrongdoing, and thus she deliberately refuses to try to offset B's wrongdoing. ${ }^{11}$

We forgive in this "pure" sense when we blame an agent and also believe that our punishing her would not offset her wrongful harm, and therefore, for that reason, we refuse to punish her. In other words, the forgiver believes that the

\footnotetext{
7 One might balk at my suggestion that Zaibert is here claiming that all blame is private in light of the fact that he introduces his conditions for blame with the phrase, "A blames B for Xing when $[\ldots]$," which suggests that he is only giving a set of sufficient conditions for blame. However, he explicitly states, prior to giving his conditions for blame, punishment, and forgiveness that " $[\mathrm{t}]$ he analyses of each of these phenomena should make these differences [between them] explicit” (Zaibert, 'The Paradox of Forgiveness', p. 387). This suggests that he is intending to give a set of necessary and sufficient conditions. Hence my suggestion that Zaibert is claiming that all blame is private.

8 Ibid., p. 387.

9 Ibid., p. 385.

10 Ibid., p. 387.

11 Ibid.
} 
wrongdoer should still be punished because such punishment would make the world a better place, and yet the forgiver also holds the belief (true or not) that were she to punish, her punishing the wrongdoer would make the world a worse place. When she forgives she therefore refrains from punishing for that reason.

Not all forgiveness is solely "pure," for sometimes pure forgiveness is communicated. When one forgives in this other, "communicative sense" of forgiveness, conditions (1-8) are met, in addition to:

(9) A communicates to B, or to someone else, that she has forgiven (in the sense of a pure mental phenomenon) B. ${ }^{12}$

Zaibert then claims that blame can be extended either in the direction of punishment (in which case, condition (8') is met in conjunction with (1-7)), or in the direction of forgiveness (in which case either condition(s) (8) or (8-9) is/are met in conjunction with (1-7)), but that blame cannot be extended (on pain of irrationality) in both directions at the same time. ${ }^{13}$ That is, at any given time, the conjunction of (8) and (8') is not satisfiable. If one punishes, one does not forgive, and if one forgives, one does not punish.

We can therefore gloss Zaibert's accounts of the two kinds or senses of forgiveness as follows:

(PF) A purely forgives B when A blames B, A believes that A's punishing $B$ would make the world a worse place, and A deliberately refuses to punish B on that basis.

(CF) A communicatively forgives $\mathrm{B}$ when $\mathrm{A}$ communicates to $\mathrm{B}$ that $\mathrm{A}$ has purely forgiven $\mathrm{B}$.

\section{Blame, Punishment and Forgiveness}

There are at least three problems with Zaibert's claims about blame, punishment, and forgiveness. First, consider the following pair of claims: that blame is exclusively private, and that when blame is acted upon, this amounts to punishment. Both of these claims are mistaken. First, as many writers on blame have argued, blame may be both privately and overtly manifested. ${ }^{14}$

\footnotetext{
12 Ibid.

13 Ibid.

${ }_{14}$ See, for example: Michael McKenna, Conversation and Responsibility (forthcoming with Oxford University Press), Ishtiyaque Haji, Moral Appraisability: Puzzles, Proposals, and Perplexities
} 
Private blame involves the manifestation of a disposition to regard the wrongdoer in a certain way. According to a very popular view, the relevant kind of regard involves the manifestation of one of the so-called "reactive attitudes," for example, resentment, indignation, or disapprobation. ${ }^{15}$

Sometimes, however, we may not only manifest a disposition to regard the wrongdoer in a certain way, we may also manifest a disposition to treat (or respond to) her in a certain way. When these dispositions are made manifest in certain ways, one engages in overt blame. Overt blame is therefore blame's outward manifestation. Examples of overt blaming behavior include reproach, censure, shunning, outright denunciation, the suspension of friendly relations, and other expressions of anger, hostility, or disapproval, such as a disapproving facial grimace or a gentle reprimand. Because we can blame both privately and overtly, Zaibert is therefore mistaken to think that all blame is private. $^{16}$

Naturally, Zaibert might object that this is simply a verbal quibble. He might reply that what I am calling overt blame he is calling punishment and that we are simply arguing over who gets to use what words. But this is not simply a verbal quibble, for overt blame and punishment are importantly different: whereas punishment essentially involves the intention to cause pain, overt blame does not. Recall that Zaibert's view of punishment is retributivist; when we inflict pain on a wrongdoer as a response to the wrongdoing she has done, we do so with the express purpose of "offsetting" that wrong. All things being equal, according to a retributivist picture, the world is a better place when wrongs are offset in this way. The goal of punishment is therefore to inflict pain upon the wrongdoer, and when we punish we do so in order to offset the wrongful harm that was done. When one punishes one plans to

(New York, NY: Oxford University Press, 1998), R. Jay Wallace, Responsibility and the Moral Sentiments (Cambridge, MA: Harvard University Press, 1994), and Michael J. Zimmerman, An Essay on Moral Responsibility (Totowa, New Jersey: Rowman and Littlefield, 1988).

15 See, for example: John Martin Fischer and Mark Ravizza, Responsibility and Control: A Theory of Moral Responsibility (Cambridge: Cambridge University Press, 1998), Paul Russell, Freedom and Moral Sentiment: Hume's Way of Naturalizing Responsibility (Oxford: Oxford University Press, 1995), John Martin Fischer, Metaphysics of Free Will: An Essay on Control (Cambridge: Blackwell, 1994), Wallace, Responsibility and the Moral Sentiments (1994), and P.F. Strawson, 'Freedom and Resentment,' Proceedings of the British Academy Vol. 48, (1962).

${ }_{16}$ Zaibert might reply that there is no such thing as overt blame, just blame expressed. Even supposing we grant this, I will argue: (1) we can express blame in a way that is not equivalent to punishment; and (2) we can express blame in a way incompatible with forgiveness. So whether we call it "overt blame" or "blame expressed," this makes little difference for my purposes here. My thanks to Eve Garrard for drawing this point to my attention. 
inflict pain. In other words: when one punishes one intends to inflict pain. That is the point of retributive punishment. ${ }^{17}$

But overt blame does not necessarily involve an intention to inflict pain. Suppose I tell a mildly embarrassing joke about you at dinner. Were you to give me a disapproving grimace from across the table, or later on gently reprimand me for treating you in that way, you need not do so with the intention of causing me pain. Your intention may simply be to communicate to me, through some way or another, that I have not treated you with due regard. But to do that is not to punish me, for punishment involves, as we have seen, the intention to cause pain. Now it may very well be true that your disapproving grimace or gentle reprimand does in fact cause me pain in some way. It may very well also be true that you knowingly and intentionally cause me pain by gently reprimanding me. But to do something knowingly and intentionally is not the same as intending to do it. ${ }^{18}$ You may knowingly and intentionally cause me pain by blaming me, and yet view the pain that you cause me as a "regrettable derivative," a foreseen yet undesired byproduct of your plan, which, let us say, is to express your disapproval of how I have treated you. And yet because punishment requires an intention to cause pain, punishing and overtly blaming come apart, both conceptually and in practice. ${ }^{19}$ We should therefore conclude that Zaibert is mistaken on two counts: that all blame is private, and that all blame that is overtly expressed amounts to punishment.

${ }^{17}$ Cf. Joel Feinberg, Doing of Deserving: Essays in the Theory of Responsibility (Princeton: Princeton University Press, 1970): "It is an essential and intended element of punishment [...] that the victim be made to suffer and of liability that he be made to pay; these are not mere regrettable derivatives of the undertakings, but rather their termini ad quem."

${ }_{18}$ For example, suppose I decide to pick up a book at the library this afternoon. I therefore form the intention to pick up a book at the library. That is my plan, what I intend to do. Suppose I did what I intended to do: I picked up the book. In picking up the book, I walked along a certain sidewalk in order to get to the library. I walked along a certain sidewalk intentionally —as an accepted way to accomplish my plan-but I did not intend to walk along that specific sidewalk because that was not part of my plan, which was simply to pick up a book at the library. While walking along the sidewalk I also come to discover that the backs of my new shoes are painfully opening up little wounds on my heels. While I am knowingly opening up little wounds on my heels, I am not intentionally wounding my heels, nor did I intend to wound my heels. This is because it was neither my plan to wound my heels nor was it an accepted part of the means to accomplishing my plan that I wound my heels. For more on the distinctions between intending, doing intentionally, and doing knowingly, see Alfred Mele and Steve Sverdlik, 'Intention, Intentional Action and Moral Responsibility,' Philosophical Studies 82 (1996), pp. 265-287, as well as McKenna, Conversation and Responsibility (forthcoming).

${ }_{19}$ For more on the relation between blame and punishment, one may consult McKenna, Conversation and Responsibility (forthcoming). 
As we have seen, some blame is overt, and overt blame is not equivalent to punishment.

These two problems for Zaibert cause a third, for even if one refused to punish a wrongdoer (whether one communicates this refusal or not), this would not entail that one would also refuse to blame her overtly and deliberatively. In other words, it is consistent with Zaibert's analysis of forgiveness that one forgives and yet continues overtly and deliberately to blame a wrongdoer, provided that one's blaming does not involve an intention to cause pain. But this is certainly mistaken.

To see why, suppose that after my inappropriate dinner joke you "forgive" me in both of Zaibert's senses. That is, you refuse to punish me on the grounds that you believe that were you to do so, the pain you would thereby cause me would, instead of offsetting my wrongdoing and making the world a better place, make the world a worse place. You also communicate to me that you have purely forgiven me. But you were greatly offended by my joke, and you believe that a strong message of disapproval ought to be communicated to me. The message needs to be strong because I am hard-hearted and fail to see why you were offended by my joke. So you give me a disapproving scowl, a stern reprimand, and you withhold what were previously normal and frequent invitations to social outings. You even tell me that you have strong feelings of moral anger over what I have done. You often bring up my offense as a topic of conversation and demand that I apologize. And yet you deliberately engage in each of these activities - many of which may constitute overt blame-all the while reassuring me that you have forgiven me for what I have done. Am I to take your claim of forgiveness seriously? Surely not: competent speakers of the language who had experience with our moral practices would be greatly puzzled by such a claim. You have not forgiven me for telling the inappropriate joke if you are still deliberately holding it against me-still demanding that I apologize and give account for what I have done. But if you have not forgiven me, then forgiveness cannot be the refusal to punish, for that you have done. Forgiveness is therefore not the deliberate refusal to punish.

\section{Collecting Results}

I have argued that Zaibert's account of forgiveness rests on three errors. First, contrary to his account of blame, not all blame is exclusively private for some blame is overt. Second, contrary to his claim that the outward manifestation of private blame is punishment, I have argued that there is a difference between overt blame and punishment: one can overtly blame without 
thereby punishing. Third, I have argued that the deliberate refusal to punish is not sufficient for forgiveness, for one can deliberately refuse to punish and still continue to blame overtly and deliberately. However, as our example makes clear, it is inconsistent with forgiveness that you continue overtly and deliberately to blame me in this way. ${ }^{20}$

${ }^{20}$ I am grateful to Eve Garrard and Justin Capes, who offered helpful comments on a previous draft, and to everyone who has ever forgiven me. 